DOI 10.37882/2223-2982.2021.11.31

\title{
ОРГАНИЗАЦИЯ ПРОФИЛАКТИЧЕСКОЙ РАБОТЫ С ПОДРОСТКАМИ С ИСПОЛЬЗОВАНИЕМ ТЕХНОЛОГИИ БИБЛИОТЕРАПИИ
}

\section{ORGANIZATION OF PREVENTIVE WORK WITH ADOLESCENTS USING BIBLIOTHERAPY TECHNOLOGY \\ E. Skachkova N. Khalitova}

Summary: The technology of bibliotherapy can be used for conscious creative study of works of art to resolve their own internal and external conflicts of adolescents. The purpose of the article is to describe and analyze the introduction of bibliotherapy technology in preventive work with adolescents. The study identified key problematic issues characteristic of adolescents: relationships with adults, relationships with peers, adolescent self-identification. They are used for the criteria for the selection of literary material: the correspondence of the text to the age characteristics of a teenager; the presence of a situation as close as possible to the situation from the real life of a teenager; the artistic value of the work; the absence of a book in the program lists for literature. A card index of artistic works of modern Russian and foreign literature, distributed by problem groups, has been compiled. Effective educational and educational tools for working with texts have been selected within the framework of the author's course «Pharmacy for the Soul». The effectiveness of bibliotherapy technology is determined by the final study, which highlights the discussion of cases in groups - specific situations from the life of adolescents. In conclusion, the prospects and reproducibility of the author's course, built on the basis of bibliotherapy technology, which contributes to the correction of adolescent behavior and changes in their emotional state, are determined.

Keywords: teenagers, upbringing, preventive work, bibliotherapy, fiction.

\author{
Скачкова Елена Анатольевна \\ сочиальный педагог, МБОУ \\ «Гимназия №48 им. Н. Островского г. Челябинска» \\ skaalena@bk.ru \\ Халитова Наталья Юрьевна \\ педагог-библиотекарь, МБОУ \\ «Гимназия №48 им. Н. Островского г. Челябинска» \\ natur07@rambler.ru
}

Аннотация: Технология библиотерапии может использоваться для осознанного творческого изучения художественных произведений для разрешения собственных внутренних и внешних конфликтов подростков. Цель статьи описание и анализ внедрения технологии библиотерапии в профилактической работе с подростками. В ходе исследования выявлены ключевые проблемные вопросы, характерные для подростков: взаимоотношения со взрослыми, взаимоотношения со сверстниками, самоидентификация подростка. Они использованы для критериев отбора литературного материала: соответствие текста возрастным особенностям подростка; наличие ситуации, максимально приближенной к ситуации из реальной жизни подростка; художественная ценность произведения; отсутствие книги в программных списках по литературе. Составлена картотека художественных произведений современной русской и зарубежной литературы, распределенных по проблемным группам. Отобраны эффективные воспитательные и образовательные инструменты для работы с текстами в рамках авторского курса «Аптека для души». Эффективность технологии библиотерапии определена итоговым исследованием, в котором выделяется обсуждение кейсов в группах - конкретных ситуаций из жизни подростков. В заключение определена перспективность и воспроизводимость авторского курса, выстроенного на основе технологии библиотерапии, которая способствует коррекции поведения подростков и изменения их эмоционального состояния.

Ключевые слова: подростки, воспитание, профилактическая работа, библиотерапия, художественная литература.

трудной жизненной ситуации. В этой связи важна эффективная профилактическая работа, которая направлена на коррекцию поведения подростка и изменение его эмоционального состояния. При этом важно формировать нравственную позицию и ответственное отношение к своей жизни (Кузнецова, 2015) и повышать качество жизни в результате разрешения проблем и трудностей развития (Степанова и др., 2019).

Продуктивную профилактическую работу с детьми на ступени основного общего образования необходимо организовать с учетом таких современных воспитательных технологий, которые бы помогли подросткам в поиске жизненного пути и разрешении ситуации трудного нравственного выбора. Библиотерапия выступает той техно- 
логией, которая позволяет не только влиять на эмоциональное состояние подростка, но и корректировать его поведение. Она понимается как «процесс сопровождения самоопределения ученика при помощи чтения книг и их рефлексивного анализа» (Соколова, 2016, с. 2826). В основе библиотерапии лежат преимущественно художественные произведения, персонажи которых способствуют развитию эмпатии и расширению диапазона испытываемых эмоций, необходимых для стимулирования воображения, замены тревожных мыслей, позитивного мышления, поиска альтернативных путей решения проблем (Вассерберг, 2017; Ревуцкая и др., 2020).

«Обращение к литературным текстам - увлекательный и ненавязчивый способ психологической коррекции» (Блаувельт, 2020, с. 16). Работа с текстами современной русской и зарубежной художественной литературы, предназначенной для подростков, предполагает осознанное творческое изучение произведений для разрешения внутренних и внешних конфликтов. При этом классическая литература отвечает на «вечные» вопросы, в то время как современная литература в дополнение поднимает актуальные проблемы сегодняшнего дня. Литературный текст «влияет на психическое состояние человека, затрагивает глубокие процессы и болезненные состояния» (Ковалева, Мартынова, 2019, с. 52).

Целью статьи является описание и анализ внедрения технологии библиотерапии в профилактической работе с подростками. Среди задач выделяются следующие:

1. Выявить ключевые проблемные вопросы, характерные для пубертатного периода, и использовать их в качестве критерия отбора литературного материала.

2. Составить картотеку художественных произведений современной русской и зарубежной литературы, распределенных по проблемным группам.

3. Отобрать эффективные современные воспитательные инструменты для работы с текстами художественной литературы как средством коррекции поведения учащихся и изменения их эмоционального состояния.

4. Описать итоговое исследование среди учащихся, охваченных циклом занятий, на предмет выявления эффективности применяемой в профилактической работе технологии.

Опыт внедрения технологии библиотерапии связан с проведением авторского воспитательного проекта «Аптека для души». Целью проекта является коррекция поведения учащихся группы риска средствами библиотерапии, способствующей разрешению внутренних и внешних конфликтов, поиску жизненного пути, принятию верного решения в ситуации трудного нравственного выбора. Он организован как цикл классных часов для обучающихся 5-8 классов из группы социального риска и проводится педагогом-психологом, социальным педагогом МБОУ «Гимназия № 48 г. Челябинска». Занятия курса проводятся как в микрогруппах в классных коллективах, так и индивидуально, например, по запросу родителей, и могут быть включены в индивидуальный план работы с учащимися, состоящими на профилактическом учете. Так получается увеличить зону воздействия на учащихся, поскольку одновременно проводится и активная профилактическая работа с учашимися, склонными к асоциальному поведению, и пропедевтическая работа с подростками с благополучным социальным статусом.

Анектирование учащихся 5-8 классов выявило круг проблем, волнующих подростков МБОУ «Гимназия № 48 г. Челябинска». Данные проблемы были разделены на три группы: взаимоотношения со взрослыми (мир детей и родителей, учителей и учащихся и пр.), взаимоотношения со сверстниками (мир общения, дружба, любовь и пр.) и самоидентификация подростка (внутренние конфликты и связанные с ними страхи, чувства одиночества, неприятия себя и окружающего мира и пр.).

Данные проблемные группы стали основой для отбора и распределения художественных произведений в картотеке. Критериями отбора произведений для внедрения технологии библиотерапии выступили следующие: соответствие текста возрастным особенностям подростка; наличие ситуации, максимально приближенной к ситуации из реальной жизни подростка; художественная ценность произведения; отсутствие книги в программных списках по литературе.

Указанные критерии отбора произведений позволили сосредоточиться на эффективных воспитательных и образовательных инструментах работы с художественным материалом, в совокупности представляющих игровые формы. Для работы с каждым текстом выбирается тот инструмент (Таблица 1), который позволяет педагогу достичь поставленной перед занятиями цели, а именно: с помощью художественного текста скорректировать поведение и оказать влияние на эмоциональное состояние подростка. Разнообразие инструментов обусловлено необходимостью сделать каждое занятие непохожим на предыдущее, что позволяет достичь наибольшего эффекта в профилактической работе.

Указанные инструменты лежат в основе цикла занятий в рамках авторского воспитательного курса «Аптека для души». Итоговым исследованием результативности авторского курса выступает наблюдение, анкетирование, рефлексия, а также набор кейсов, представляющих собой конкретные ситуации из жизни подростков: кейсы-ситуации, кейсы-иллюстрации, кейсы-фильмы. Учащиеся в ходе работы над кейсом должны выделить проблему и представить возможные способы решения конфликтной ситуации, работая 
Таблица 1

Содержание цикла занятий с использованием технологии библиотерапии

\begin{tabular}{|c|c|c|c|}
\hline Проблемные группы & Конкретизация проблемы & Автор и название произведения & $\begin{array}{c}\text { Воспитательные и образовательные } \\
\text { инструменты }\end{array}$ \\
\hline \multirow{11}{*}{$\begin{array}{l}\text { Взаимоотношения } \\
\text { со взрослыми }\end{array}$} & \multirow{11}{*}{ учитель - учащийся } & $\begin{array}{l}\text { Бернар Фрио «Нетерпеливые истории. } \\
\text { Тишина» }\end{array}$ & $\begin{array}{l}\text { Игра «Театр абсурда»: фантастическое } \\
\text { решение проблемы }\end{array}$ \\
\hline & & Мариам Петросян «Дом, в котором...» & $\begin{array}{l}\text { Интервью с героем книги об одном } \\
\text { дне из его жизни }\end{array}$ \\
\hline & & Ракель Дж. Паласио «Чудо» & $\begin{array}{l}\text { Составление кластера «Август и } \\
\text { его учителя» }\end{array}$ \\
\hline & & Энн Файн «Пучеглазый» & $\begin{array}{l}\text { Прием «Фишбоун»: отношения } \\
\text { Пучеглазого и Китти }\end{array}$ \\
\hline & & $\begin{array}{l}\text { Виктория Ледерман «Теория } \\
\text { невероятностей» }\end{array}$ & Работа с ассоциативным рядом «семья» \\
\hline & & Юлия Кузнецова «Где папа?» & Чтение с остановками \\
\hline & & Ольга Громова «Сахарный ребенок» & 0бсуждение обложки для книги \\
\hline & & Алмонд Дэвид «Скеллиг» & Работа с киноверсией книги \\
\hline & & Рэй Брэдбери «Мальчик-невидимка» & $\begin{array}{l}\text { Прием «дерево предсказаний»: } \\
\text { как закончится рассказ? }\end{array}$ \\
\hline & & Наринэ Абгарян «Манюня» & Инсценирование эпизодов \\
\hline & & Кэтрин Эпплгейт «Креншоу» & $\begin{array}{l}\text { Игра «Если бы я был героем книги, } \\
\text { я бы никогда...» }\end{array}$ \\
\hline \multirow{10}{*}{$\begin{array}{l}\text { Взаимоотношения } \\
\text { со сверстниками }\end{array}$} & \multirow{5}{*}{ дружба и любовь } & $\begin{array}{l}\text { Виктория Ледерман «Теория невероят- } \\
\text { ностей» }\end{array}$ & $\begin{array}{l}\text { Игра «Дискуссионный клуб «Новый } \\
\text { член семьи» }\end{array}$ \\
\hline & & Ракель Дж. Паласио «Чудо» & Прием «Придумай новое название» \\
\hline & & Игорь Свинин «Наследники Триглава» & Создание ленты жизни Ланека \\
\hline & & Эдуард Веркин «0блачный полк» & Прогнозирование событий \\
\hline & & $\begin{array}{l}\text { Антон Соя «Правдивая история Федери- } \\
\text { ко Рафинелли» }\end{array}$ & Прием чимборасо \\
\hline & \multirow{5}{*}{ ребенок-изгой } & $\begin{array}{l}\text { Марина Мартиросова «Фотографии на } \\
\text { память» }\end{array}$ & Прием «Искусанного кусают все» \\
\hline & & Мариам Петросян «Дом, в котором. ...» & Прием РАФТ \\
\hline & & Ракель Дж. Паласио «Чудо» & Пересказ текста от лица Джулиана \\
\hline & & Юлия Кузнецова «Где папа?» & Использование ментальных карт \\
\hline & & $\begin{array}{l}\text { Максуд Ибрагимбеков «За все } \\
\text { хорошее - смерть» }\end{array}$ & Создание портретной галереи героев \\
\hline \multirow{8}{*}{$\begin{array}{l}\text { Самоидентификация } \\
\text { подростка }\end{array}$} & \multirow{4}{*}{ о проблемах взросления } & Анна Анисимова «Гутя» & $\begin{array}{l}\text { Создание диаграммы Венна «Августа и } \\
\text { Дашка» }\end{array}$ \\
\hline & & Мариам Петросян «Дом, в котором» & $\begin{array}{l}\text { Прием «До и после» («Хозяин Дома»: } \\
\text { предугадывание событий) }\end{array}$ \\
\hline & & $\begin{array}{l}\text { Андрей Жвалевский, Евгения Пастернак } \\
\text { «Время всегда хорошее» }\end{array}$ & Прием «Могу спросить обо всем» \\
\hline & & $\begin{array}{l}\text { Эрик-Эммануэль Шмитт «0скар и розо- } \\
\text { вая дама» }\end{array}$ & Создание ленты другой «жизни» Оскара \\
\hline & \multirow[t]{2}{*}{ о детских страхах } & $\begin{array}{l}\text { Бернар Фрио «Нетерпеливые истории. } \\
\text { Штуковина» }\end{array}$ & Работа с ассоциациями: «страх» и «смех» \\
\hline & & Кадзуми Юмото «Друзья» & Прием «дерево предсказаний» \\
\hline & \multirow{2}{*}{ о правде и лжи } & Ася Петрова «Волки на парашютах» & Прием «мимическая гимнастика» \\
\hline & & Илья Зверев «Второе апреля» & Инсценирование \\
\hline
\end{tabular}


в группах. При этом сначала группам представляется содержание кейса и предлагается ситуация. Далее рассматриваются и обсуждаются предложенные ситуации, варианты решения проблемы и аргументы; педагог обобщает ответы, оценивает действия учащихся. В заключение организуется презентация и экспертиза результатов деятельности групп, проводится общая оценка работы группы над кейсом и самооценка.

Курс «Аптека для души» представляется перспективным, так как картотека текстов русской и зарубежной литературы позволит в дальнейшем расширить круг проблем, затронутых авторами-современниками и являющихся актуальными для подростковой среды 5-8 классов. Неоспоримым достоинством курса является его воспроизводимость в условиях любой образовательной организации при наличии педагога, готового не только использовать в своей работе актуальные воспитательные и образовательные инструменты, но и осознать и освоить потенциал современного литературного процесса как безграничного ресурса для работы с учащимися группы социального риска.

\section{ЛИТЕРАТУРА}

1. Блаувельт Е.И. Итоги экспериментальной работы, направленной на коррекцию смысложизненных ориентаций старших подростков в процессе группового психологического консультирования с применением элементов библиотерапии // Глобус: психология и педагогика. - 2020. - № 4 (39). - С. $16-17$.

2. Вассерберг В.В. Организация культурно-досуговой деятельности для реабилитации подростков с педагогической запущенностью. - Человек и образование. - 2017. - № 3 (52). - С. 142-146.

3. Ковалева А.В., Мартынова М.А. Развитие уверенности в себе у девочек-подростков с помощью библиотерапии (на примере анализа книги М. Глейзер «Книжные странники») // Казанский вестник молодых ученых. - 2019. - Т. 3. - № 5. - С. 50-54.

4. Кузнецова А.А. Психолого-педагогическая технология коррекции отклоняющегося поведения педагогически запущенных подростков посредством библиотерапии // Вестник Шадринского государственного педагогического института. - 2015. - № 3 (27). - С. 119-125.

5. Ревуцкая И.В., Хвасько Н.С., Фарсян К.А. Методы стабилизации эмоционального состояния подростков // Донецкие чтения 2020: образование, наука, инновации, культура и вызовы современности: мат-лы V междунар. науч. конф., г. Донецк, 17-18 нояб. 2020 г. - Т. 9. - Донецк: Изд-во ДонНУ. - С. 339-342.

6. Соколова 0.С. Использование возможностей библиотерапии для педагогического сопровождения подростков // Научно-методический электронный журнал «Концепт». - 2016. - Т. 11. - С. 2821-2825. - URL: http://e-koncept.ru/2016/86595.htm

7. Степанова 0.П., Арпентьева М.Р., Худякова Т.Л., Кузнецова Н.В. Бибилиотерапия в современных школах и вузах: процессы, результаты, возможности и ограничения // Гуманитарные науки. - 2019. - № 3 (47). - С. 165-174.

(c) Скачкова Елена Анатольевна (skaalena@bk.ru), Халитова Наталья Юрьевна (natur07@rambler.ru).

Журнал «Современная наука: актуальные проблемы теории и практики» 